\title{
Pola kunjungan serangga liar dan efek penambahan koloni Trigona (Tetragonula) laeviceps Smith pada penyerbukan kabocha (Cucurbita maxima)
}

\author{
Pattern of wild pollinator visitation and effect of innundation by \\ Trigona (Tetragonula) laeviceps Smith colonies to pollination success \\ of kabocha (Cucurbita maxima)
}

\author{
Ramadhani Eka Putra ${ }^{1}$, Julio Subagio', Ida Kinasih', \\ Agus Dana Permana', Mia Rosmiati ${ }^{1}$ \\ ${ }^{1}$ Sekolah Ilmu dan Teknologi Hayati, Labtek XI, Insitut Teknologi Bandung \\ Jalan Ganesa No. 10, Bandung 40132 \\ ${ }^{2}$ Jurusan Biologi, Universitas Islam Negeri Sunan Gunung Djati Bandung \\ Gedung Fakultas Sains dan Teknologi, Universitas Islam Negeri Sunan Gunung Djati \\ Bandung Jalan AH Nasution No. 105, Bandung 40614
}

(diterima Februari 2017, disetujui Juli 2017)

\begin{abstract}
ABSTRAK
Serangga penyerbuk liar maupun terdomestikasi memainkan peran penting dalam proses penyerbukan pada berbagai tanaman bernilai ekonomi terutama tanaman monoceious seperti dari kelompok Cucurbitaceae. Tujuan dari penelitian ini adalah mendapatkan informasi mengenai peran dari serangga penyerbuk liar dan aplikasi koloni Trigona (Tetragonula) laeviceps Smith terhadap produksi dan kualitas buah kabocha (Cucurbita maxima) sebagai model tanaman pada lahan pertanian tradisional. Pengamatan dilakukan pada pukul 07:00-15:00 selama periode pebungaan dalam kurun waktu tiga minggu. Pengamatan dilakukan pada tiga plot perlakuan: open pollination + T. laeviceps (OPT), open pollination (OP), dan hand pollination (HP). Efek dari polinator ditinjau melalui tiga parameter, yaitu pola kunjungan, plant reproductive success, dan kualitas buah. Pola kunjungan diukur berdasarkan frekuensi dan lama kunjungan serangga, plant reproductive success diukur dari fruit set dan jumlah biji, sedangkan kualitas buah diukur berdasarkan diameter dan berat buah serta produksi buah/tanaman. Hasil penelitian menunjukkan mayoritas polinator liar aktif pada pagi hari, sedangkan $T$. laeviceps lebih aktif mulai siang yang diduga disebabkan oleh pengaruh variasi toleransi terhadap suhu pada tiap spesies. Terdapat perbedaan signifikan pada fruit set antara perlakuan OPT (80\%), OP (65\%), dan HP (38,3\%) $\left(\mathrm{F}_{235}=19,907, \mathrm{P}=0,000\right)$. Jumlah biji dan kualitas buah yang dihasilkan pada perlakuan OPT dan OP lebih tinggi dibandingkan dengan perlakuan HP, sedangkan jumlah buah pada OPT jauh lebih tinggi dibandingkan dengan lainnya. Rendahnya kesuksesan penyerbukan pada plot HP menunjukkan ketepatan waktu penting bagi penyerbukan kabocha. Berdasarkan hasil ini maka penyerbukan oleh lebah pada tanaman kabocha sulit digantikan oleh manusia dan variasi kunjungan yang dimiliki oleh T. laeviceps berdampak positif pada produksi buah kabocha.
\end{abstract}

Kata kunci: kesuksesan reproduksi, produksi buah, serangga penyerbuk, tanaman produksi

\begin{abstract}
Insects hold important role in pollination of many crops. However, studies on pollination in Indonesia could be considered rare. This study focussed on obtaining the basic information of wild pollinators and the effect Trigona (Tetragonula) laeviceps Smith innundation release to the

\footnotetext{
*Penulis korespondensi: Ramadhani Eka Putra. Sekolah Ilmu dan Teknologi Hayati, Institut Teknologi Bandung, Jalan Ganesha No. 10, Bandung 40132. Tel: (022) 2511575, Faks: (022) 253410, Email: ramadhani@sith.itb.ac.id.
} 
production and quality of pumpkin (C. maxima) in traditional farming system. Observations were carried out from 07:00 to 15:00 during flowering period for 3 weeks. Sampling area was divided into three plots : open pollination $+T$. laeviceps $(\mathrm{OPT})$, open pollination $(\mathrm{OP})$, and hand pollination (HP). Pollination was assessed by three main parameters, which were visitation pattern, plant reproductive success, and fruit quality. Visitation pattern was assessed by measuring frequency and duration of pollinator visits, the plant reproductive success by fruit set and number of seed produced; while fruit quality by diameter, weight, and number of fruit produced/plant. We recorded different visitation pattern in which wild pollinator preferred to visit flowers in the morning while T. laeviceps preferred to visit from noon to afternoon. This pattern could be relate to difference in thermal tolerance among pollinators. There were significant differences among fruit set produced in OPT (80\%), OP (65\%), and HP (38.3\%) $\left(\mathrm{F}_{2,35}=19.907, \mathrm{P}=0.000\right)$. Number of seeds and fruit quality produced in OPT and OP much higher than HP while number of fruits produced in OPT significantly higher that OP and HP. Low pollination success in HP showed pollination process in pumpkin highly depend on pollination time. Thus, pollination by bees in pumpkin hard to be replace by human and variation of visit provided by T. laeviceps produce positive effect to pumpkin.

Key words: crops, fruit production, insect pollinators, reproduction success

\section{PENDAHULUAN}

Di alam, serangga berperan besar dalam memberikan servis ekosistem bagi ekosistem alami maupun buatan (Ricketts 2004; Tscharntke et al. 2005; Winfree et al. 2008). Salah satu dari servis penting yang berkaitan langsung dengan kehidupan manusia adalah penyerbukan. Proses penyerbukan sendiri penting dalam menjaga kelangsungan produksi makanan dunia karena $35 \%$ dari tanaman yang menjadi sumber pangan manusia memerlukan bantuan hewan untuk menjamin kesuksesan proses penyerbukan (Klein et al. 2007; Aizen et al. 2009). Pada berbagai sistem pertanian, serangga telah dimanfaatkan sebagai agen penyerbuk dengan lebah madu sebagai jenis serangga yang paling umum digunakan (Faegri \& van der Pijl 1979; Delapane \& Mayer 2000; Atmowidi et al. 2008; James \& Pitts-Singer 2008; Putra \& Kinasih 2014; Putra et al. 2014).

Penelitian di Indonesia menunjukkan peran penting serangga sebagai agen-agen penyerbuk pada sistem agroforestri terutama pada tanaman tahunan (Notodimejo 1995; Klein et al. 2003a, 2003b; Olschewski et al. 2006; Atmowidi et al. 2008). Akan tetapi, sebagian besar petani hortikultura di Indonesia masih menganggap tanaman hortikultura tidak begitu memerlukan bantuan serangga dalam proses penyerbukannya walaupun beberapa penelitian menunjukkan hal yang sebaliknya (Delaplane \& Mayer 2000; Greenleaf \& Kremen 2006; Fajarwati et al. 2009; Putra \& Kinasih 2014; Putra et al. 2014; Rosmiati et al. 2015; Indraswari et al. 2016).
Pada beberapa dekade terakhir, terjadi penurunan populasi lebah madu secara global, melalui fenomena yang disebut colony collapse disorder, yaitu terjadinya kematian masal individu-individu lebah madu pada satu koloni yang umumnya menyerang koloni lebah pada daerah subtropik. Penyebab dari fenomena ini diduga kombinasi beberapa faktor, antara lain tungau Varroa destructor Anderson \& Trueman, pestisida neonicotinoid, perubahan habitat, dan faktor genetik (Potts et al. 2010). Bagi daerah tropis sendiri ancaman terbesar pada populasi lebah madu tropis pada satu daerah adalah proses absconding, yaitu proses seluruh koloni anggota koloni meninggalkan sarang karena penurunan pada kondisi lingkungan maupun karena gangguan yang diterima oleh koloni (Hepburn \& Radloff 2011). Halini diperburuk dengan aktivitas pertanian yang kurang ramah lingkungan (Klein et al. 2003a, 2007). Kondisi ini mendorong kegiatan untuk pengembangan serangga-serangga penyerbuk baru melalui konservasi serangga penyerbuk liar dan domestikasi spesies lebah baru, terutama spesies non-Apis sebagai polinator alternatif bagi tanaman hortikultura guna meningkatkan produksi dan kualitas buah.

Salah satu kandidat serangga yang memiliki potensi untuk diaplikasikan sebagai agen penyerbuk pada pertanian lokal di Indonesia adalah stingless bee (Meliponini). Stingless bee memiliki koloni perrenial, bersifat generalis (polylectic), dan tersebar di kawasan beriklim tropis maupun subtropis (Michener 2000). Peranan stingless bee dalam berbagai tanaman 
pangan telah cukup terdokumentasi dengan baik, baik pada kawasan paleotropik maupun neotropik. Sebagai agen penyerbuk, lebah ini memiliki beberapa keunggulan, antara lain bersifat adaptif, mempunyai indikasi flower constancy, mudah didomestikasi, ketahanan koloni tinggi, serta mampu melakukan food recruitment (Heard 1999; Slaa et al. 2006). Di Indonesia, terdapat cukup banyak spesies stingless bee yang dapat dijumpai, terutama dari genus Trigona dengan Trigona (Tetragonula) laeviceps Smith sebagai spesies yang paling umum ditemukan (Sakagami 1978).

Famili Cucurbitaceae merupakan salah satu kelompok tanaman hortikultura yang bergantung pada jasa agen penyerbuk karena bersifat monoesis (Pacini 1992; Freeman et al. 1997; Ashworth \& Galetto 2002). Baik bunga jantan maupun betina memiliki masa anthesis yang berlangsung selama satu hari (Loy 2004). Jumlah biji yang dihasilkan dari proses penyerbukan pada Cucurbit sangat ditentukan oleh jumlah serbuk sari yang diterima oleh putik (pollen limited) sehingga hubungan antara deposit serbuk sari oleh polinator spesifik dan kesuksesan penyerbukan dapat diukur secara langsung (Walters \& Taylor 2006). Baik bunga jantan maupun betina, pada Cucurbit mulai mekar sekitar pukul 05:00-06:00. Antesis berlangsung selama satu hari dan bunga menutup seiring penurunan reseptivitas stigma dan viabilitas serbuk sari. Waktu penutupan bunga dapat bervariasi bergantung pada kondisi cuaca, yaitu pada kisaran pukul 13:00 hingga 15:00. Penutupan bunga berlangsung selama kurang lebih satu jam (Nepi \& Pacini 1993). Karena waktu antesis yang sangat terbatas ditambah dengan pentingnya proses penyerbukan bagi pembentukan biji menjadikan tanaman Cucurbit sebagai tanaman model yang baik untuk mempelajari interaksi antara tanaman dengan penyerbuk alami dan terdomestikasi.

Penelitian ini bertujuan untuk mengevaluasi proses penyerbukan pada tanaman kabocha (Cucurbita maxima) oleh polinator liar dan meninjau pengaruh penambahan aplikasi koloni stingless bee, khususnya T. laeviceps serta pengaruhnya pada produksi dan kualitas buah kabocha.

\section{BAHAN DAN METODE}

\section{Persiapan penelitian}

Penelitian dilakukan pada bulan JuliSeptember 2016 di lahan pertanian tradisional yang terletak di Desa Wangun Harja, Cikidang, Cikareumbi, Cikole, Lembang, Kabupaten Bandung Barat. Lokasi lahan pertanian memiliki ketinggian sekitar $1.400 \mathrm{~m}$ dpl, dengan suhu ratarata tahunan $23-25{ }^{\circ} \mathrm{C}$ dan kelembaban rata-rata tahunan sekitar 74-82\%. Penelitian dilakukan pada tiga plot perlakuan, yakni plot open pollination (OP) yang merupakan plot untuk pengamatan penyerbukan oleh serangga penyerbuk liar, plot hand pollination (HP) yang merupakan plot untuk pengamatan penyerbukan dengan bantuan manusia, dan plot open pollination $+T$. laeviceps $(\mathrm{OP}+\mathrm{T})$ yang merupakan plot untuk pengamatan efek penambahan koloni $T$. laeviceps terhadap proses penyerbukan. Masing-masing plot terdiri atas 12 tanaman kabocha, tersusun berbaris dalam 3 ruas, dengan jarak antar ruas sekitar $1 \mathrm{~m}$ dan jarak antar tanaman dalam satu ruas sekitar $2 \mathrm{~m}$, setiap tanaman berperan sebagai ulangan (Gambar 1). Pemupukan dilakukan pada awal penanaman dengan campuran pupuk kandang dan kompos serta setiap dua minggu dengan pupuk NPK mutiara (11: $11: 11)$. Pada plot hand pollination, bunga betina ditutup dengan selubung kain kasa sebelum antesis dan setelah penyerbukan silang manual dengan tangan. Pada plot open pollination $+T$. laeviceps, sebanyak dua koloni T. laeviceps ditempatkan di tengah plot, sedangkan plot open pollination berperan sebagai kontrol dimana kunjungan T. laeviceps ke bunga dihindari dengan melakukan pengusiran dan penangkapan individu yang mendekati bunga. Penempatan koloni $T$. laeviceps dimulai sebelum munculnya bunga jantan yang mengalami antesis setelah sebelumnya diaklimatisasi selama kurang lebih satu minggu. Proses penyerbukan oleh tangan dilakukan pada pukul 07:00 bersamaan dengan waktu dimulainya pengamatan pada penyerbukan oleh serangga.

\section{Pengamatan aktivitas mencari makanan dan frekuensi kunjungan}

Pengamatan aktivitas mencari makanan dilakukan pada plot $\mathrm{OP}+\mathrm{T}$ dengan mencatat jumlah individu T. laeviceps yang keluar sarang dan masuk 

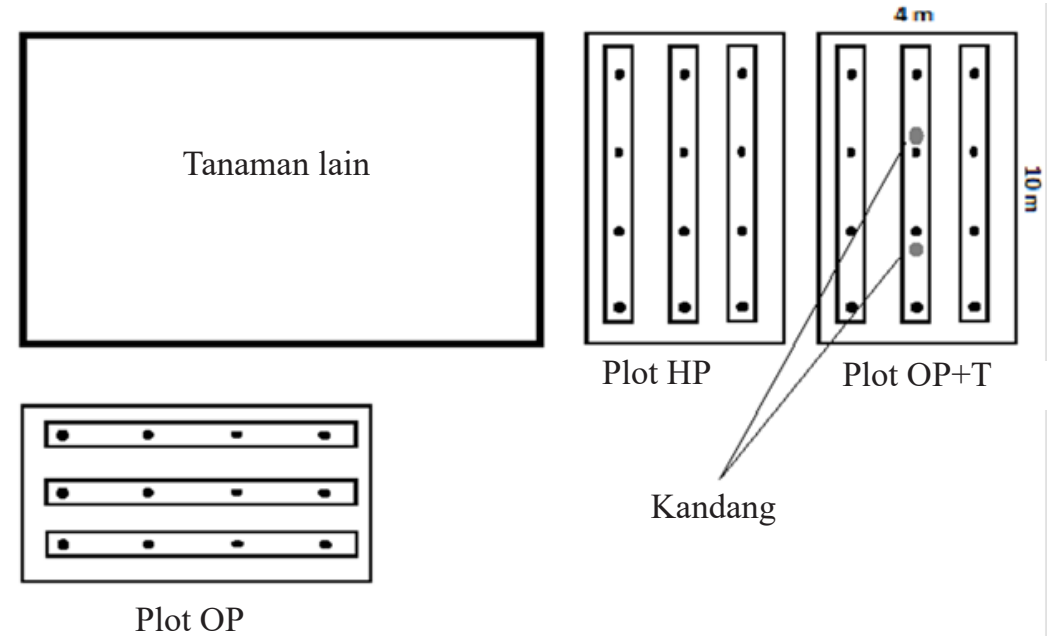

Gambar 1. Denah plot perlakuan. Setiap noktah hitam mewakili satu tanaman kabocha.

kembali dengan membawa serbuk sari selama 10 menit untuk setiap jam. Aktivitas kunjungan diamati pada plot $\mathrm{OP}$ dan $\mathrm{OP}+\mathrm{T}$ untuk setiap spesies yang mengunjungi bunga. Pengamatan kunjungan dilakukan menggunakan metode focal sampling pada 30 bunga betina di setiap plot, meliputi jumlah individu yang mengunjungi bunga selama 10 menit (visitation frequency) dan lama kunjungan per bunga (handling time). Kedua jenis pengamatan dilakukan secara simultan mulai pukul 07:00-15:00 pada hari cerah dengan tutupan awal maksimal 40\% (Klein et al. 2003b), dalam periode keberadaan bunga kabocha pada bulan Agustus 2016. Total waktu pengamatan untuk keseluruhan penelitian adalah 40 jam. Perilaku serta morfologi khusus tiap spesies juga turut diamati. Selama pengamatan, kelembaban dan temperatur udara juga turut diukur.

\section{Pengamatan plant reproductive success, produksi} dan kualitas buah

Pengamatan plant reproductive success dilakukan dengan cara menandai 30 bunga betina pada masing-masing plot sehari sebelum antesis. Pengamatan dilakukan setelah bunga betina antesis sesuai dengan plot perlakuan. Plant reproductive success dihitung berdasarkan persentase fruit set, yaitu total buah yang terbentuk dibagi total keseluruhan bunga betina yang diamati. Produksi total buah dihitung dari setiap plot perlakuan. Parameter kualitas buah yang diukur adalah diameter, berat buah, dan jumlah biji.

\section{Analisis data}

Hubungan aktivitas mencari makanan dan parameter lingkungan diuji dengan menggunakan 72 korelasi Pearson. Data produksi dan kualitas buah dianalisis dengan menggunakan one way analysis of variance (ANOVA) dengan selang kepercayaan 95\% dilanjutkan dengan least significant difference (LSD) sebagai post hoc test. Seluruh proses data dianalisis dengan menggunakan perangkat lunak SPSS 17.0.

\section{HASIL}

\section{Aktivitas mencari makanan dan frekuensi kunjungan}

Aktivitas mencari makanan T. laeviceps dimulai sekitar pukul 07:00 atau saat temperatur mencapai $21{ }^{\circ} \mathrm{C}$. Jumlah individu lebah pencari makanan yang keluar dari sarang terus meningkat hingga mencapai puncaknya pada pukul 11:00 (34,5 $\pm 11,54$ individu), dan mengalami penurunan setelahnya hingga pukul 15:00. Kecenderungan yang sama juga terjadi pada lebah pencari makanan yang membawa serbuk sari kembali ke sarang (Gambar 2).

Berdasarkan hasil korelasi Pearson antara aktivitas mencari makanan $T$. laeviceps dengan temperatur dan kelembaban, didapat nilai $r$ $=0,68 \quad(\mathrm{P}=0,327)$ untuk temperatur dan $\mathrm{r}$ $=-0,41 \quad(\mathrm{P}=0,822)$ untuk kelembaban. Hal ini menunjukkan tidak terdapat hubungan antara perilaku mencari makan $T$. laeviceps dengan parameter temperatur dan kelembaban.

Selama pengamatan, tercatat terdapat tujuh spesies polinator liar yang teramati mengunjungi bunga kabocha. Secara keseluruhan, hampir semua polinator liar aktif pada pagi hari, mulai dari pukul 07:00 dan mengalami penurunan pada 
sekitar pukul 10:00-11:00. Frekuensi kunjungan pada $T$. laeviceps mulai mengalami peningkatan signifikan pada pukul 09:00, dan mencapai puncak pada pukul 11:00 sebelum mengalami penurunan setelah sekitar pukul 12:00. Ditinjau dari pola frekuensi kunjungan, dapat terlihat bahwa terdapat pembagian berdasarkan waktu (temporal partitioning) diantara spesies serangga pengunjung bunga (Gambar 3).

Analisa menggunakan korelasi Pearson menunjukkan hubungan kuat antara temperatur dan pola frekuensi kunjungan pada hampir seluruh spesies (Tabel 1). Hal ini mengindikasikan adanya variasi toleransi panas akibat perbedaan ukuran

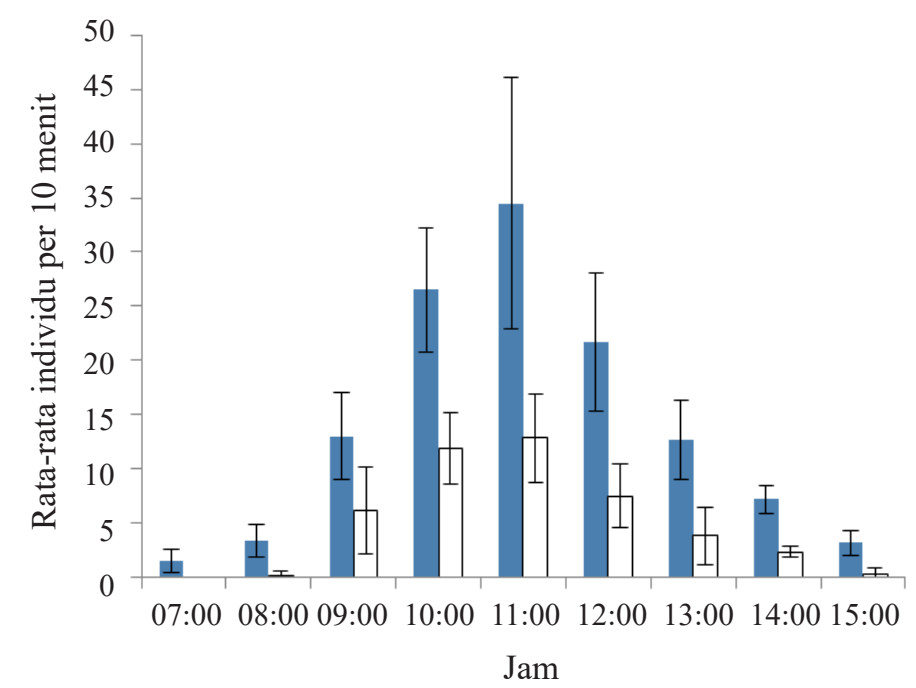

Gambar 2. Pola aktivitas mencari makanan harian pada Trigona (Tetragonula) laeviceps. $\approx$ : mencari makan; $\square$ : kembali dengan polen.

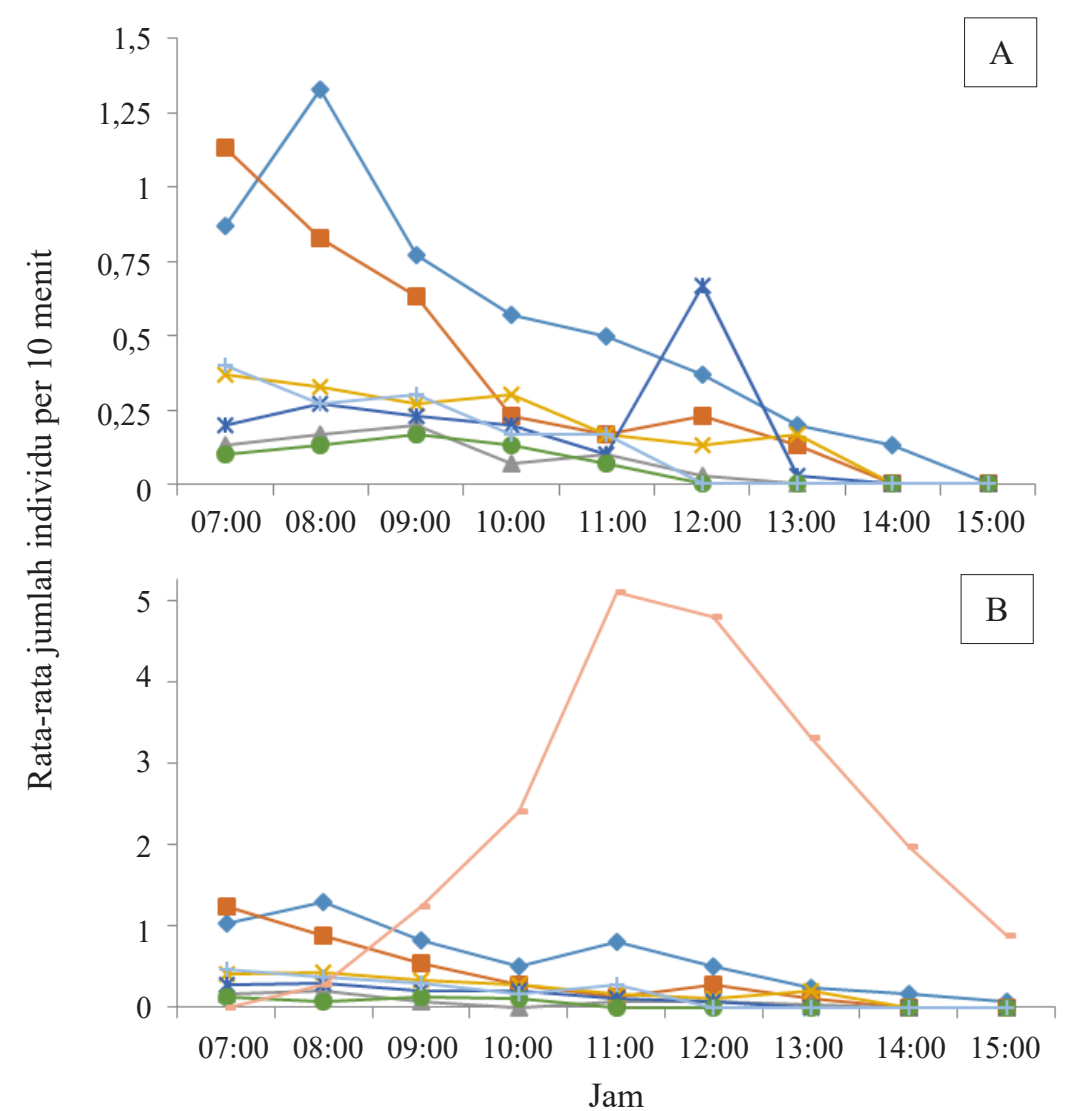

Gambar 3. Frekuensi kunjungan pada plot $\mathrm{OP}(\mathrm{A})$ dan plot $\mathrm{OP}+\mathrm{T}(\mathrm{B}) . \rightarrow-$ : Vespa velutina; $\rightarrow-$ : Xylocopa caerulea; $\rightarrow$ : Amegilla zonata $\rightarrow-$ : Campsomeris sp.; $\rightarrow$ *:Xylocpa latipes; $\rightarrow-$ Nomia sp. $\rightarrow:$ Xylocopa aestuans; - : Trigona (Tetragonula) laeviceps. 
tubuh dan kolorasi pada setiap spesies, terutama mengingat terjadinya peningkatan temperatur yang linear dan konstan hingga sore hari (Gambar 4).

\section{Plant reproductive success, produksi, dan kualitas buah}

Secara keseluruhan, tanaman kabocha pada plot $\mathrm{OP}+\mathrm{T}$ memiliki fruit set yang secara signifikan lebih tinggi dibandingkan dengan plot OP dan HP. $\left(\mathrm{F}_{2,35}=19,907, \mathrm{P}=0,000\right)$, sedangkan untuk parameter kualitas buah, ditinjau dari diameter, berat, dan jumlah biji, tidak terdapat perbedaan signifikan antara plot $\mathrm{OP}+\mathrm{T}$ dan OP. Pada plot HP, seluruh parameter produksi dan kualitas buah menunjukkan hasil yang lebih rendah dan berbeda signifikan dibandingkan dengan kedua plot lain (Tabel 2).

\section{PEMBAHASAN}

Temperatur dan radiasi mempengaruhi aktivitas mencari makanan dengan menentukan threshold temperatur (energi minimum) terjadinya aktivitas terbang, serta membatasi durasi mencari makanan, dan meningkatkan resiko terjadinya overheat, terutama saat terbang, terkait dengan metabolic heat production (Hrncir \& Maia 2013). Spesies berukuran besar relatif melakukan aktivitas makan lebih awal karena mampu meningkatkan

Tabel 1. Matriks koefisien korelasi Pearson (r) untuk frekuensi kunjungan dengan parameter lingkungan

\begin{tabular}{lcc}
\hline Spesies & Temperatur udara & Kelembaban udara \\
\hline Vespa velutina & $-0,84^{* *}$ & $0,71^{* *}$ \\
Xylocopa caerulea & $-0,93^{* *}$ & 0,63 \\
Amegilla zonata & $-0,29$ & 0,41 \\
Campsomeris sp. & $-0,87^{* *}$ & $0,71^{*}$ \\
Xylocopa latipes & $-0,91^{* *}$ & 0,65 \\
Nomia sp. & $-0,81^{* *}$ & 0,52 \\
Xylocopa aestuans & $-0,94^{* *}$ & 0,61 \\
Trigona (Tetragonula) laeviceps & 0,68 & $-0,41$
\end{tabular}

$* \mathrm{P}<0,05 ; * * \mathrm{P}<0,01$.

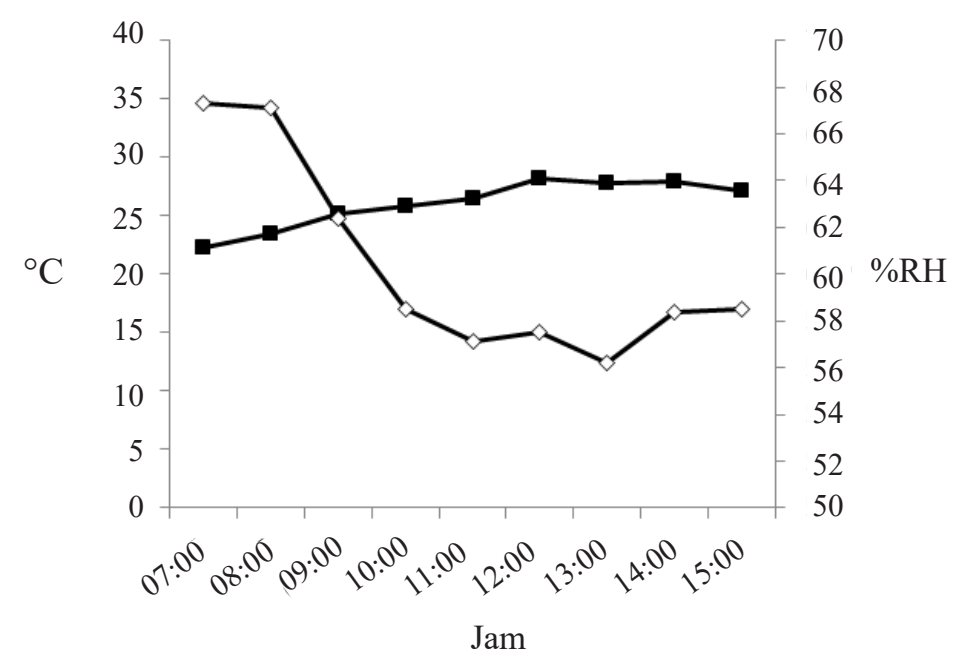

Gambar 4. Temperatur dan kelembaban relatif pada lokasi penelitian. $\rightarrow-$ : suhu udara; $\multimap-$ : kelembaban.

Tabel 2. Perbandingan parameter produksi dan kualitas buah pada tiap plot perlakuan

\begin{tabular}{lccccc}
\hline Plot perlakuan & $\begin{array}{c}\text { Fruit set } \\
(\%)\end{array}$ & $\begin{array}{c}\text { Diameter buah } \\
(\mathrm{cm})\end{array}$ & Berat buah & Jumlah biji & $\begin{array}{c}\text { Produksi buah/ } \\
\text { tanaman }\end{array}$ \\
\hline Open pollination + T. laeviceps & 80 & $17,9 \pm 1,15 \mathrm{a}$ & $1,62 \pm 0,21 \mathrm{a}$ & $273,87 \pm 38,43 \mathrm{a}$ & $4,75 \pm 0,86 \mathrm{a}$ \\
Open pollination & 65 & $17,58 \pm 0,27 \mathrm{a}$ & $1,59 \pm 0,27 \mathrm{a}$ & $258,87 \pm 25,54 \mathrm{a}$ & $4,08 \pm 0,67 \mathrm{~b}$ \\
Hand pollination & 38,3 & $15,27 \pm 1,26 \mathrm{~b}$ & $1,26 \pm 0,30 \mathrm{~b}$ & $225,73 \pm 18,57 \mathrm{~b}$ & $2,83 \pm 0,72 \mathrm{c}$ \\
\hline
\end{tabular}

Huruf yang berbeda pada kolom sama menunjukan perbedaan signifikan pada selang kepercayaan 95\%. 
temperatur tubuh mereka melalui pergerakan otot terbang, sedangkan spesies berukuran kecil, seperti Trigona bergantung pada suhu lingkungan untuk mendapatkan temperatur tubuh minimal bagi beraktivitas yang diperkirakan berkisar antara $18-19{ }^{\circ} \mathrm{C}$ (Heard \& Hendrikz 1993). Faktor lain yang mempengaruhi adalah perbedaan surface to volume ratio terkait dengan ukuran tubuh. Faktor ini dapat mempengaruhi proses konveksi panas dimana resiko overheat pada individu berukuran kecil jauh lebih rendah. Hal ini mungkin dapat menjelaskan preferensi serangga kecil untuk beraktivitas pada suhu udara lebih tinggi di siang hari (Pereboom \& Biesmeijer 2003).

Berdasarkan analisis statistik, kelembaban tidak berpengaruh signifikan terhadap frekuensi kunjungan. Akan tetapi, kelembaban relatif berbanding terbalik dengan suhu dan keduanya menentukan konsentrasi nektar (Willmer \& Stone 2004). Konsentrasi gula nektar cenderung meningkat pada siang hari akibat evaporasi. Pada umumnya, konsentrasi gula nektar pasca sekresi, biasa pada pagi hari, berkisar antara $12-34 \%$. Trigona sendiri memiliki preferensi konsentrasi gula sekitar 35-60\%, yang mungkin dapat ditemukan pada nektar saat siang hari sehingga koleksi nektar terjadi pada tengah hingga siang hari (Inoue et al. 1985).

Kombinasi antara variasi morfologi, ukuran tubuh, preferensi sumber daya, dan interaksinya dengan parameter lingkungan menyebabkan terbentuknya pembagian waktu (temporal partitioning) antar spesies. Berdasarkan hasil pengamatan, seluruh spesies pengunjung kabocha dapat dibagi ke dalam beberapa kelompok spesies fungsional/guild berdasarkan paramater kuantitatif (ukuran tubuh, periode kunjungan, dan handling time) dan parameter kualitatif (morfologi dan perilaku pada bunga) (Tabel 3). Pembagian guild ini digunakan sebagai pendekatan untuk memprediksi potensi peranan tiap spesies dalam proses penyerbukan.

Kelompok Xylocopa (guild A), memiliki handling time relatif singkat karena perilaku mencari makanan yang efektif. Profosis yang pendek namun besar menyebabkan koleksi nektar berlangsung cepat, terlebih pada pagi hari keberadaan nektar melimpah. Xylocopa juga dapat melakukan sonikasi (perilaku menggetarkan kepala sari dalam frekuensi tinggi) sehingga dapat melepas serbuk sari dari kepala sari dalam jumlah besar (Michener 2000). Serbuk sari kemudian akan menempel pada bulu di bagian dorsal toraks, atau sekeliling tungkai terutama pada scopa. Strategi mencari makanan dengan melakukan trap-lining mengakibatkan Xylocopa memiliki area mencari makanan yang luas (Liow et al. 2001; Momose \& Hamid-Karim 2005). Kombinasi faktor tersebut, ditambah dengan tingkat kelimpahan yang tinggi antara 6 hingga 10 individu per jam selama pengamatan menjadikan guild ini diduga berperan besar dalam proses transfer serbuk sari pada kabocha (Gambar 3).

Kelompok tawon (guild B) terdiri atas Vespa dan Campsomeris. Keduanya memiliki tubuh ramping dan relatif besar. Perbedaan mencolok antara keduanya adalah keberadaan bulu lebat pada Campsomeris (Michener 2000). Keberadaan bulu pada Campsomeris menyebabkan serangga ini dapat berperan dalam proses penyerbukan terutama pada tumbuhan dari kelompok anggrek (Ciotek et al. 2006), macadamia (Vithanage \& Ironside 1986), dan timun (Clarisa \& Kasmara 2016). Campsomeris juga menggunakan nektar

Tabel 3. Klasifikasi guild spesies pengunjung kabocha berdasarkan parameter ukuran tubuh, periode kunjungan, dan handling time

\begin{tabular}{lcccl}
\hline Spesies & $\begin{array}{c}\text { Ukuran tubuh } \\
(\mathrm{mm})\end{array}$ & $\begin{array}{c}\text { Waktu kunjungan ke } \\
\text { bunga }\end{array}$ & $\begin{array}{c}\text { Handling time } \\
(\mathrm{s})\end{array}$ & Guild \\
\hline Xylocopa caerulea & $18-22$ (besar) & $07: 00-13: 00$ & $5,59 \pm 1,23$ & A (Xylocopa) \\
Xylocopa aestuans & $18-22$ (besar) & $07: 00-11: 00$ & $4,14 \pm 0,11$ & \\
Xylocopa latipes & $30-34$ (besar) & $07: 00-11: 00$ & $5,88 \pm 0,31$ & \\
\hline Vespa velutina & $20-24$ (besar) & $07: 00-14: 00$ & $13,57 \pm 1,32$ & B (Tawon) \\
Campsomeris sp. & $22-25$ (besar) & $07: 00-13: 00$ & $8,50 \pm 0,79$ & \\
\hline Nomia sp. & $11-13$ (sedang) & $07: 00-10: 00$ & $8,50 \pm 0,79$ & C (Lebah sedang) \\
Amegilla zonata & $11-13$ (sedang) & $07: 00-09: 00$ & $4,02 \pm 0,31$ & \\
\hline Trigona (Tetragonula) laeviceps & $4-4,6$ (kecil) & $09: 00-15: 00$ & $27,23 \pm 3,02$ & D (Lebah kecil) \\
\hline
\end{tabular}


dan polen pada bunga sebagai sumber energi dan protein selain dari pemangsaan, aktivitas yang berkontribusi pada proses penyerbukan pada kelompok tumbuhan yang terbatas (Reddy \& Reddi 1994). Vespa sendiri tidak mengandalkan seluruh sumber protein dari mangsa sehingga tidak melakukan koleksi serbuk sari secara sengaja, akan tetapi kelompok serangga ini mengkonsumsi nektar sebagai sumber karbohidrat utama (Ren et al. 2014; Ueno 2015). Serangga ini diduga berperan dalam proses penyerbukan berdasarkan pada fakta bahwa (1) terdapat serbuk sari yang menempel pada tubuh mereka, (2) tingkat kunjungan yang relatif tinggi pada bunga, bahkan tertinggi dibandingkan dengan lebah lain (Gambar 3). Hipotesis ini tentu saja perlu diujikan pada penelitian di masa depan

Amegilla dan Nomia dimasukkan ke dalam kelompok lebah berukuran sedang (guild C). Perilaku mencari makanan pada Amegilla mirip dengan Xylocopa. Akan tetapi, kerena kedua spesies ini memiliki abundansi paling kecil selama pengamatan, informasi detail mengenai perilaku mencari makanan dari kelompok ini tidak dapat diperoleh dengan sempurna.

Trigona digolongkan ke dalam kelompok lebah berukuran kecil (guild D). Trigona juga bersifat eusosial dan dapat melakukan pencarian makanan secara berkelompok (group foraging) sehingga ditemukan dalam jumlah relatif tinggi pada bunga kabocha. Kelompok pencari makanan dari koloni Trigona menghabiskan waktu cukup lama saat mengunjungi bunga betina. Hal dapat disebabkan oleh beberapa hal, yaitu ukuran bunga yang jauh lebih besar dibandingkan dengan lebah, viskositas nektar yang tinggi, serta perilaku Trigona dalam bunga. Trigona seringkali mengelilingi bunga untuk pindah dari satu pori ke pori lain, dan terjadi kontak terutama dengan bagian bawah lobus stigma. Hal ini meningkatkan probabilitas distribusi serbuk sari pada tiap lobus.

Perbedaan kelompok fungsional ini secara tidak langsung memberikan efek yang berbeda dalam proses penyerbukan kabocha. Hal ini juga berkaitan dengan perbedaan morfologi bunga jantan dan betina pada kabocha. Pada bunga jantan, serbuk sari pada atheriferous column memiliki probabilitas yang sama untuk dapat menempel pada tubuh pengunjung saat datang maupun pergi.
Namun pada bunga betina, deposit serbuk sari dalam jumlah besar terjadi pada saat datangnya pengunjung, dimana lobus stigma bagian atas akan menerima sebagian besar serbuk sari, sedangkan lobus bagian bawah hanya menerima sisa serbuk sari seiring pergerakan pengunjung di sekeliling nectary cup (Nepi \& Pacini 1993).

Spesies berukuran besar, seperti Xylocopa bertanggung jawab atas deposit serbuk sari dalam jumlah besar pada stigma, sedangkan spesies berukuran kecil seperti Trigona berperan dalam distribusi serbuk sari yang merata pada seluruh bagian lobus stigma melalui perilakunya yang mengitari bagian dalam bunga saat koleksi nektar (Hoehn et al. 2008).

Keberadaan guild (kelompok) yang beragam akibat keragaman spesies yang tinggi dapat berperan positif pada agroekosistem dengan mengurangi tingkat redundansi antar polinator karena terbentuknya relung yang saling komplementer untuk membentuk interaksi tanaman dan penyerbuk yang berkesinambungan (Klein et al. 2008).

Aplikasi koloni Trigona meningkatkan produktivitas tanaman kabocha mengingat aktivitas mencari makanan yang relatif lebih siang dibandingkan dengan spesies lain sehingga secara tidak langsung memperkecil terbuangnya serbuk sari yang sebelumnya tidak dikoleksi oleh spesies lain sehingga meningkatkan peluang terjadinya penyerbukan yang cukup. Handling time Trigona yang cukup lama juga berpengaruh terhadap deposit serbuk sari khususnya pada lobus stigma bagian bawah.

Pada plot HP, baik hasil maupun kualitas buah lebih rendah dan memiliki perbedaan signifikan dengan kedua plot lain. Namun demikian, penyebab kegagalan terbentuknya fruit set tidak dapat dipastikan mengingat tidak dilakukannya pengukuran stigmatik pengendapan serbuk sari pada tiap bunga. Besar kemungkinan hal ini disebabkan oleh masalah teknis dibanding proses penyerbukannya. Terdapat dua hipotesis mengenai penyebab fenomena ini, yaitu: (1) Serbuk sari yang diterima stigma tidak cukup banyak sehingga tidak terbentuk banyak fruit set dan (2) Penggunaan kain kasa sebagai selubung bunga menyebabkan kelembaban relatif dalam bunga sangat tinggi menyebabkan penurunan reseptivitas stigma dan 
viabilitas serbuk sari, terlebih mengingat kedua proses berlangsung sebelum bunga antesis.

Deposit serbuk sari merupakan salah satu faktor pembatas dalam pembentukan buah tanaman Cucurbit. Buah baru akan terbentuk setelah adanya deposit serbuk sari yang merata pada setiap lobus stigma. Meski demikian, terdapat proses seleksi pasca penyerbukan yang menentukan hasil akhir produktivitas tanaman. Alokasi sumber daya yang terbatas akan membuat tanaman memprioritaskan bakal buah dengan jumlah biji terbanyak sehingga keberadaan buah yang sedang berkembang akan meningkatkan probabilitas terjadinya aborsi buah dan menghambat produksi bunga betina (Stephenson et al. 1988). Hal ini menjadikan penambahan koloni dengan tujuan untuk membantu proses penyerbukan perlu diperhitungkan secara holistik agar keberadaannya mampu meningkatkan produksi secara optimal.

\section{KESIMPULAN}

Keberadaan Trigona juga tidak mengganggu aktivitas polinator liar karena adanya temporal partitioning yang erat kaitannya dengan variasi morfologi dan ukuran tubuh. Kondisi ini membentuk realized niche bagi masing-masing spesies pengunjung bunga kabocha yang tidak berselingkupan dimana masing-masing spesies dapat memegang peranan yang berbeda berkaitan dengan proses penyerbukan. Secara keseluruhan, penambahan koloni Trigona berdampak positif pada produksi buah kabocha, terdapat perbedaan signifikan pada produksi buah per tanaman bila dibandingkan dengan kedua perlakuan lain. Aktivitas pencari makanan yang relatif lebih siang secara tidak langsung mengurangi terbuangnya serbuk sari yang tidak ditransfer oleh polinator lain sehingga berujung pada peningkatan laju penyerbukan dan produktivitas tanaman kabocha.

\section{UCAPAN TERIMA KASIH}

Penulis mengucapkan terima kasih kepada Bapak Yoni dan Ibu Cacih karena telah mengizinkan peminjaman lahan pertaniannya untuk keperluan penelitian. Sebagian dari penelitian ini dibiayai oleh Penelitian Unggulan Perguruan Tinggi tahun 2017 yang diterima oleh penulis korespondensi.

\section{DAFTAR PUSTAKA}

Aizen MA, Garibaldi LA, Cunningham SA, Klein AM. 2009. How much does agriculture depend on pollinators? Lessons from long-term trends in crop production. Annals of Botany 103:15791588. doi: https://doi.org/10.1093/aob/mcp076.

Ashworth L, Galetto L. 2002. Differential nectar production between male and female flowers in a wild cucurbit: Cucurbita maxima ssp. andreana (Cucurbitaceae). Canadian Journal of Botany 80: 1203-1208. doi: https://doi.org/10.1139/b02-110.

Atmowidi T, Riyanti P, Sutrisna A. 2008. Pollination effectiveness of Apis cerana Fabricus and Apis mellifera Linnaeus (Hymenopter: Apidae) in Jatropha curcas L. (Euphorbiaceae). Biotropia 15:129-134.

Ciotek L, Giorgis P, Benitez-Vieyra S, Cocucci AA. 2006. First confirmed case of pseudocopulation in terrestrial orchids of South America: pollination of Geoblasta pennicillata (Orchidaceae) by Campsomeris bistrimacula (Hymenoptera, Scoliidae). Flora 201:365-369. doi: https://doi. org/10.1016/j.flora.2005.07.012.

Clarisa D, Kasmara H. 2016. Keanekaragaman serangga penyerbuk tanaman mentimun (Cucumis sativus L.) di Balai Penelitian Tanaman Sayuran (Balitsa), Lembang, Jawa Barat. Prosiding Seminar Nasional MIPA Jatinangor 27-28 Oktober 2016. Tersedia di: http://riset.fmipa.unpad.ac.id/data/ uploads/paper/semnas/2016/032.-158-163-dania clarisa-2.pdf [diakses 21 Februari 2017].

Delapane KS, Mayer DF. 2000. Crop Pollination by Bees. Cambridge: CAB International Press. doi: https://doi.org/10.1079/9780851994482.0000.

Faegri K, van der Pijl L. 1979. The Principles of Pollinating Biology. London: Pergammon Press Ltd.

Fajarwati MR, Atmowidi T, Dorly. 2009. Keanekaragaman serangga pada bunga tomat (Lycopersicon esculentum Mill.) di lahan pertanian organik. Jurnal Entomologi Indonesia 6:77-85.

Freeman DC, Lovett DJ, Elkeblawy A, Miglia KJ Mcarthur ED. 1997. Sexual specialization and inbreeding avoidance in the evolution of dioecy. The Botanical Review 63:65-92. doi: https://doi. org/10.1007/BF02857918.

Greenleaf SS, Kremen C. 2006. Wild bee species increase tomato production but respond diffe- 
rently to surrounding land use in Northern California. Biological Conservation 133:81-87. doi: https://doi.org/10.1016/j.biocon.2006.05.025.

Heard TA, Hendrikz JK. 1993. Factors influencing flight activity of colonies of stingless bee Trigona carbonaria (Hymenoptera: Apidae). Australian Journal of Zoology 41:343-353. doi: https://doi. org/10.1071/ZO9930343.

Heard TA. 1999. The role of stingless bees in crop pollination. Annual Review of Entomology 44: 183-206. doi: https://doi.org/10.1146/annurev. ento.44.1.183.

Hepburn C, Radloff SE. 2011. Honeybees of Asia. Springer-Verlag, Berlin: Heidelberg, Germany. doi: https://doi.org/10.1007/978-3-642-16422-4.

Hoehn P, Tschamtke T, Tylianakis JM, SteffanDewenter I. 2008. Functional group diversity of bee pollinators increases crop yield. Proceedings of the Royal Society 275:2283-2291. doi: https:// doi.org/10.1098/rspb.2008.0405.

Hrncir M, Maia-Silva C. 2013. On the diversity of foraging-related traits in stingless bees. In: Vit P, Pedro SR, Roubik, DW (Eds.), Pot-Honey A Legacy of Stingless Bee. pp. 201-215. New York: Springer, Sciences+Business Media. doi: https://doi.org/10.1007/978-1-4614-4960-7_13.

Indraswari AG, Atmowidi T, Kahono S. 2016. Keanekaragaman, aktivitas kunjungan, dan keefektifan lebah penyerbuk pada tanaman tomat (Solanum lycopersicum L: Solanaceae). Jurnal Entomologi Indonesia 13:21-29. doi: https://doi. org/10.5994/jei.13.1.21.

Inoue T, Salmah S, Abbas I, Yusuf E. 1985. Foraging behavior of individual workers and foraging dynamics of colonies of three Sumatran stingless bees. Researches on Population Ecology 27:373392. doi: https://doi.org/10.1007/BF02515474.

James RR, Pitts-Singer TL. 2008. Bee Pollination in Agricultural Ecosystems. New York: Oxford University Press. doi: https://doi.org/10.1093/ac prof:oso/9780195316957.001.0001.

KleinAM, Cunningham SA, Bos M, Steffan-Dewenter I. 2008. Advances in pollination ecology from tropical plantation crops. Ecology 89:935-943. doi: https://doi.org/10.1890/07-0088.1.

Klein AM, Steffan-Dewenter I, Tscharntke T. 2003a. Fruit set of highland coffee increases with the diversity of pollinating bees. Proceeding of the Royal Society of London, Series B: Biological Sciences 270:955-961. doi: https://doi. org/10.1098/rspb.2002.2306.

Klein AM, Steffan-Dewenter I, Tscharntke T. 2003b. Pollination of Coffea canephora in relation to local and regional agroforestry management. Journal of Applied Ecology 40: 837-845. doi: https://doi.org/10.1046/j.13652664.2003.00847.x.

Klein AM, Vaissière BE, Cane JH, Steffan-Dewenter I, Cunningham SA, Kremen C, Tscharntke T. 2007. Importance of pollinators in changing landscapes for world crops. Proceedings of the Royal Society of London Series B - Biological Sciences. 274:303-313. doi: https://doi. org/10.1098/rspb.2006.3721.

Liow LH, Sodhi NS, Elmqvist T. 2001. Bee diversity along a disturbance gradient in tropical lowland forests of South-East Asia. Journal of Applied Ecology 38:180-192. doi: 10.1046/j.13652664.2001.00582.x.

Loy JB. 2004. Morpho-Physiological aspect of productivity and quality in squash and pumpkins (Cucurbita spp.). Critical Reviews in Plant Sciences 23:337-363. doi: https://doi. org/10.1080/07352680490490733.

Michener CD. 2000. The Bees of The World. London: John Hopkins University Press.

Momose K, Hamid-Karim AA. 2005. The plantpollinator community in a lowland dipterocarp forest. In: Roubik DW, Sakai S, Hamid-Karim AA. (Eds), Pollination Ecology and the Rain Forest Sarawak Studies. pp. 65-72. New York: Springer Science+Business Media. doi: https:// doi.org/10.1007/0-387-27161-9_6.

Nepi M, Pacini E. 1993. Pollination, pollen viability and pistil receptivity in Cucurbita pepo. Annals of Botany 72:527-536. doi: https://doi. org/10.1006/anbo.1993.1141.

Notodimejo S. 1995. Influence of growth regulators Dormex, Promalin, foliar fertilizer Algifert and release of honey bees on the development and production of mango in East Java. Agrivita 18: 43-50.

Olschewski R, Tscharntke T, Benítez PC, Schwarze S, Klein A. 2006. Economic evaluation of pollination services comparing coffee landscapes in Ecuador and Indonesia. Ecology and Society 11: 7. doi: https://doi.org/10.5751/ES-01629-110107.

Pacini E. 1992. Seduction and deception in pollen and seed dispersal. Giornale Botanico Italiano 126:161-168. doi: https://doi.org/10.1080/112 63509209430273.

Pereboom JJ, Biesmeijer JC. 2003. Thermal constraints for stingless bee foragers: the importance of body size and coloration, Oecologia 137:42-50. doi: https://doi.org/10.1007/s00442003-1324-2. 
Potts SG, Biesmeijer JC, Kremen C, Neumann P, Scweiger O, Kunin WE. 2010. Global pollinator declines: Trends, impacts, and drivers. Trends in Ecology and Evolution 25:345-353. doi: https:// doi.org/10.1016/j.tree.2010.01.007.

Putra RE, Permana AD, Kinasih I. 2014. Application of asiatic honey bees (Apis cerana) and stingless bees (Trigona laeviceps) as pollinator agents of hot pepper (Capsicum annuum L.) at local Indonesia farm system. Psyche 2014:687979. doi: https://doi.org/10.1155/2014/687979.

Putra RE, Kinasih I. 2014. Efficiency of local Indonesia honey bees (Apis cerana L.) and stingless bee (Trigona iridipennis) on Tomato (Lycopersicon esculentum Mill.) Pollination. Pakistan Journal of Biological Sciences 17:8691. doi: https://doi.org/10.3923/pjbs.2014.86.91.

Reddy TB, Reddi CS. 1994. Pollination ecology of Vitex negundo (Verbenaceae). Proceeding of the Indian National Science Academy B60:57-66.

Ren ZX, Wang H, Bernhardt P, Li DZ. 2014. Insect pollination and self-incompatibility in edible and/or medicinal crops in southwestern china, a global hotspot of biodiversity. American Journal of Botany 101:1700-1710. doi: https://doi. org/10.3732/ajb.1400075.

Ricketts TH. 2004. Tropical forest fragments enhance pollinator activity in nearby coffee crops. Conservation Biology 18:1262-1271. doi: https:// doi.org/10.1111/j.1523-1739.2004.00227.x.

Rosmiati M, Putra RE, Ruswandi A. 2015. Insects pollination of zucchini farming in Indonesia and their economic importance. Asian Journal of Plant Science 14:84-88. doi: https://doi. org/10.3923/ajps.2015.84.88.

Sakagami SF. 1978. Tetragonula stingless bees of the continental Asia and Sri Lanka (Hymenoptera: Apidae). Journal of the Faculty of Science Hokkaido University Series Zoology 21:165-247.
Slaa EJ, Chaves LA, Malagodi-Braga KS, Hofstede FE. 2006. Stingless bees in applied pollination: practice and perspectives. Apidologie 37:293315. doi: https://doi.org/10.1051/apido:2006022. Stephenson AG, Devlin B, Horton JB. 1988. The effects of seed number and prior fruit dominance on the pattern of fruit production in Cucurbita pepo (Zucchini squash). Annals of Botany 62:653-661. doi: https://doi.org/10.1093/ oxfordjournals.aob.a087705.

Tscharntke T, Klein AM, Kruess A, Steffan-Dewenter I, Thies C. 2005. Landscape perspectives on agricultural intensification and biodiversityecosystem service management. Ecology Letters 8:857-874. doi: https://doi.org/10.1111/j.14610248.2005.00782.x.

Ueno T. Flower-visiting by the invasive hornet Vespa velutina nigrithorax (Hymenoptera: Vespidae). International Journal of Chemical, Environmental \& Biological Sciences 3:444-448.

Vithanage V, Ironside DA. 1986. The insect pollinators of macadamia and their relative importance. Journal of the Australian Institute of Agricultural Science. 52:155-160.

Walters SA, Taylor BH. 2006. Effects of honey bee pollination on pumpkin fruit and seed yield. Horticultural Science 41:370-373. doi: https:// doi.org/10.1590/S0100-84042010000100010.

Willmer PG, Stone GN. 2004. Behavioral, ecological, and physiological determinants of the activity patterns of bees. Advances in the Study of Behavior 34:347-466. doi: https://doi. org/10.1016/S0065-3454(04)34009-X.

Winfree R, Williams NM, Gaines H, Ascher JS, Kremen C. 2008. Wild bee pollinators provide the majority of crop visitation across land-use gradients in New Jersey and Pennsylvania, USA. Journal of Applied Ecology 45:793-802. doi: https://doi. org/10.1111/j.1365-2664.2007.01418.x. 